\title{
スリット入り鋼板耐震壁付鉄骨骨組の弾塑性挙動 ELASTIC-PLASTIC BEHAVIOR OF BUILDING STEEL FRAME INCORPORATIONG STEEL BEARING WALL WITH SLITS
}

\author{
日高桃子*, 松井千秋**, 津田 恵吾***, 貞 包佳秀**** \\ 今村輝 武*****, 畑戸龍夫****** \\ Toko HITAKA, Chiaki MATSUI, Keigo TSUDA, Yoshihide SADAKANE, \\ Terutake IMAMURA and Tatsuo HATATO
}

\begin{abstract}
Steel Bearing Wall with Slits has been proved to be an earthquake-resisting element with high energy absorption capacity through experiments, and the design formulae we had proposed showed good agreement to the test results. Those experiments, however, focused on the wall's behavior with an idealized boundary condition. In this paper, the experiment on the steel building frame with steel bearing wall with slit is shown. This paper aims to make clear the behaviors and the mutual effects of the wall and the frame when attached to each other, and to check the applicability of the proposed design formulae.
\end{abstract}

Keywords : steel bearing wall, building steel frame, slit, strength, stiffness, mutual effect 鋼板耐震壁、鉄骨建築骨組、スリット、耐力、㓮性、相互作用

\section{1. はじめに}

近年、エネルギー的観点から、層間変形角が小さい範囲での地 震入力エネルギーを耐震要素で集中的に吸収し、鉛直荷重を支持す る主体構造の損傷を防ぐことを期待した設計が行われるようになっ てきた。更に、建築構造物の動的解析から、このような構造を実現 する為には、構造物における耐震要素の耐力と剛性の適切な配置が 必要であることが分かってきている 1)。た、性能設計が求められ る現在、勒性があり、設計耐力及び剛性を簡易に変えることが可能 な耐震要素が求められている。

以上の要求に応える耐震要素として、これまでにスリット入り 鋼板耐震壁の開発を行ってきた。スリット入り鋼板耐震壁は、図 1 に示すように鋼板に縦にスリットを入机ることにより、スリットで 挟まれた部分（以下、この部分を柱状部とよぶ。またその他の部分 を壁部とよぶ）が柱材のような曲げ挙動をし、大きな変形能力を発 揮する。耐震壁の耐力は柱状部の塑性耐力で評価でき、また、耐震 壁の剛性は柱状部の曲げ変形の影響が支配的であり、柱状部の寸法 及ひ配置、言い換えるとスリットの入れ方を変えることにより耐震 壁の耐力及び剛性を独立的に決定することが可能である。既に、単 体の酎震壁に対して実験を行い、耐力及び剛性の設計式を提案し、 設計式の妥当性を確認している2。
但し、単体実験においては、耐震壁の拘束条件を単純にする為 に、耐震壁を載荷装置の梁に取り付けるアングルおよびボルトには、 その剛性及び耐力が過大になるようなものを用いており、また、耐 震壁全体としての反曲点が耐震壁の中央に位置するように、載荷装 置は、耐震壁が変形する間、上及び下の載荷梁が互いに平行を保つ よう設計されていた。

しかし、実用時において、耐震壁が骨組の中で挙動する時には、 耐震壁はそれが取り付けられる梁の変形の影響を受け、また反对に、 梁は耐震壁から伝わる剪断力や曲げモーメントの影響を受けると考 えられる。特に、本耐震壁は梁間スパンを全ては使わないような使 用を考えており、その場合、梁の耐震壁が取り付けられていない部 分の応力状態や变形を考慮する必要がある。

今回、以上の耐震壁と骨組の相互に及ぽす影響を調べる為に、耐 震壁については耐力及び剛性が異なる 2 種類の耐震壁を、骨組につ いては梁の柱に対する剛比が異なる 2 種類の鉄骨門形骨組を実験変 数とし、繰返水平力載荷実験を行った。以下、実験の詳細、結果及 び考察を述べ、スリット入り鋼板耐震壁が骨組に組込まれた時の耐 震壁及び骨組の挙動を明らかにする。
九州大学大学院人間環境学研究科空間システム専攻 大学院生·工修

* 九州大学大学院人間環境学研究科空間システム専攻 教授. 工博

** 九州大学大学院人間環境学研究科空間システム専攻 助教授・王博

九州大学大学院人間環境学研究科然間システム専攻 大学院生

***** 前田建設工業侏建築技術 (開発) $\mathrm{G}$

****** 前田建設工業侏開発営業部
Graduate Student, Architectural Structures and Materials, Graduate School of Human Environment Studies, Kyushu University, M. Eng. Prof., (Same as*), Dr. Eng.

Assoc. Prof., (Same as*), Dr. Eng.

Graduate Student (Same as*), B. Eng.

Technical Development Sect., Maeda Corp. Development and Coordination Division, Maeda Corp. 


\section{2. 耐力・㓮性提案式}

これまでの単体の耐震壁の実験に基いて提案した耐震壁の耐力 $\left(\mathbf{Q}_{\mathrm{wa}}\right)$ 及び剛性 $\left(\mathbf{K}_{\mathrm{wa}}\right)$ の評価式は、以下の(1)及び(2)式である。

$$
\begin{aligned}
& \mathbf{Q}_{\mathrm{wa}}=\frac{\mathbf{M}_{\mathrm{p}}}{\mathbf{l} / 2} \cdot \mathbf{n}=\frac{\mathbf{n t b ^ { 2 }}}{2 \mathrm{I}} \cdot \sigma_{\mathrm{y}} \\
& \mathbf{K}_{\mathrm{wa}}=\frac{\mathbf{h}}{\frac{\mathbf{k ( h - m l )}}{\mathbf{G B t}}+\frac{\mathbf{k d}}{\mathbf{G b t}} \cdot \frac{\mathbf{m}}{\mathbf{n}}+\frac{(1+\mathbf{b})^{3}}{\mathbf{E t b}^{3}} \cdot \frac{\mathbf{m}}{\mathbf{n}}}
\end{aligned}
$$

ここに、 $\mathbf{M}_{\mathbf{p}}$ : 柱状部の断面の全塑性モーメント、 $\sigma_{\mathrm{y}}$ :鋼板の降伏応

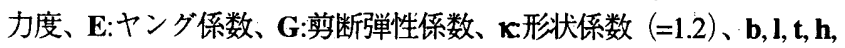
$\mathbf{B}, \mathbf{n}$ 及び $\mathbf{m}$ に関しては、図 1 の) 参照。

耐力式(1)では、耐震壁の柱状部の上下端が全塑性曲げモーメン 卜に達する時の、耐震壁の水平方向力を耐力として算定し、剛性式 (2)では、水平力 $\mathbf{Q}$ がかかっている時の耐震壁各部の剪断変形と柱 状部の曲け変形を考慮して剛性を算定している。

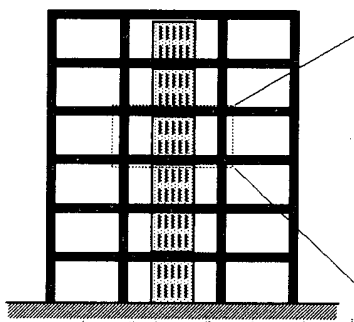

(a) “耐震壁付骨組

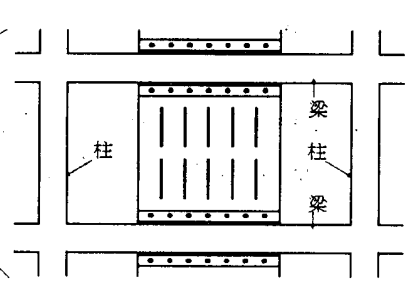

(b) 耐震壁と部材の構成

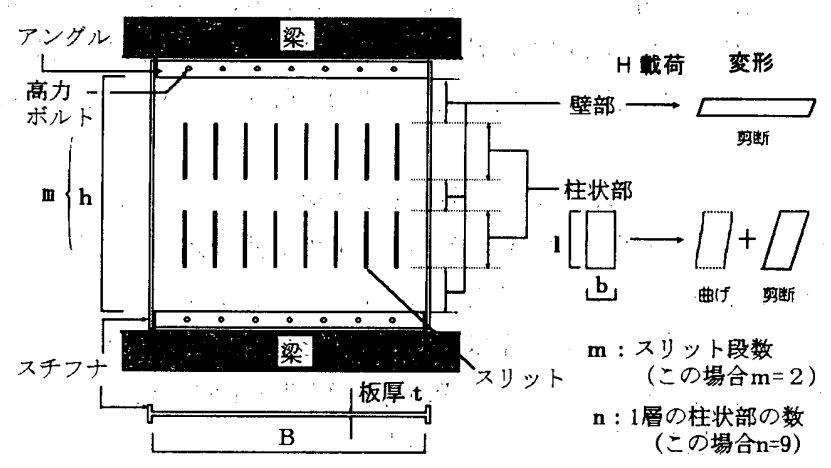

(c) 詳細図

図1 スリット入り鋼板耐震壁

表 1 鋼材の機峨的性質

\begin{tabular}{c|c|c|c|c|c|c}
\hline \multicolumn{2}{c|}{ 鋼材 } & $\sigma_{\mathrm{y}}\left(\mathrm{t} / \mathrm{cm}^{2}\right)$ & $\sigma_{\mathrm{u}}\left(\mathrm{t} / \mathrm{cm}^{2}\right)$ & $\varepsilon_{\mathrm{y}}(\%)$ & $\varepsilon_{\mathrm{u}}(\%)$ \\
\hline \multicolumn{2}{c|}{ PL45 (耐震壁) } & 2.96 & 4.68 & 0.14 & 27.1 \\
\hline \multirow{2}{*}{ 柱 } & \multirow{2}{*}{$\mathrm{H}-100 \times 100 \times 6 \times 8$} & フランジ & 3.25 & 4.43 & 0.15 & 24.2 \\
& & ウェブ & 3.45 & 4.58 & 0.16 & 27.0 \\
\hline \multirow{2}{*}{ 梁 } & \multirow{2}{*}{$\mathrm{H}-148 \times 100 \times 6 \times 9$} & フランジ & 3.43 & 4.89 & 0.16 & 26.4 \\
& & ウェブ & 3.82 & 5.16 & 0.18 & 20.9 \\
\hline
\end{tabular}

$\sigma_{\mathrm{y}}$ : 降伏応力度、 $\sigma_{\mathrm{u}}$ : 引張強さ、 $\varepsilon_{\mathrm{y}}$ : 降伏ひずみ、 $\varepsilon_{\mathrm{u}}$ : 破断伸び

\section{3. 実䀦 \\ (1) 実験的画}

\section{a) 試験体}

試験体の一例を図 2 に示す。試験体は、下梁上面から梁の軸心 までの距離 $\mathbf{h}_{\mathbf{r}}$ を $850 \mathrm{~mm} 、$ 柱の軸心点間距離 $\mathbf{l}_{\mathbf{b}}$ を $1600 \mathrm{~mm}$ に、耐 震壁の幅 $\mathbf{B}$ を $800 \mathrm{~mm}$ 、厚さ $\mathbf{t} を 4.5 \mathrm{~mm} 、$ スリットの幅を $3 \mathrm{~mm}$

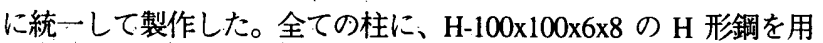
いた。

耐震壁の面外変形を抑制する為に、単体実験の試験体には、耐 震壁と同じ鋼板から製作した、幅 $50 \mathrm{~mm}$ のスチフナを耐震壁の両 横に溶接したが、骨組実験の試験体にも同様に、50mm 幅のスチ フナを溶接した。

骨組の柱梁接合部パネルの両面に、厚さ $6 \mathrm{~mm}$ のプレートを隅 肉溶接して補強した。

架構に使用した鋼材は、全て SS 400 である。その機械的性質を 表 1 に示す。耐震壁の単体実験て使用した鋼材の降伏応力度は 3.02 $\left(\mathrm{t} \mathrm{cm}^{2}\right)$ であり、骨組実験の耐震壁の降伏応力度と殆ど变わらない。

\section{実験変数}

実験変数は耐震壁の種類と梁の柱に対する剛比とした。試験体の 実験変数の一覧を表 2 に示す。

骨組に取り付けられるスリット入り 鋼板耐震壁には、スリット層 数 $\mathbf{m}$ が2、で、柱状部の幅と板厚の比 b/t が溉ね 10 及び 20 の 2 種類 の耐震壁を使用した (以後、前者の耐震壁を W102、後者の耐震壁 をW202 と呼ぶ)。

単体実験での両耐震壁の性質を述べると、W102 は大きな層間変 形の時でも耐力の劣化がなく優れたエネルギー吸収能力性能を示し、 耐力・剛性ともに提案評価式による計算值と一致が見られた。一方 W202 は、W102 と比較すると耐力と剛性がともに大きいが、層間 変形角 $\mathrm{R}=2.0(\%)$ の頃から柱状部の面外変形により耐力が劣化し始 め、実験耐力は計算耐力を 1.5 割下回った2。

骨組に関しては、H-100x100x6x8 の H 形鋼を梁に使用した骨組

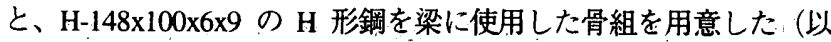
後、前者を F100 の骨組、後者を F148 の骨組と呼ぶ)。

試験体は: 2 種類の骨組に対して、耐震壁を取り付けないもの、 W102を取り付けたもの、そしてW202を取り付けたものの計 6 体 とした。試験体名中、F100 及び F148 は骨組に扔ける梁の違いを示 し、W102 及び W202 は使用した耐震壁を示し、W000 は耐震壁が 取り付けられていない試験体であることを表す。

\section{耐震壁 - 梁接合部}

耐震壁は単体実験の時と同㥞にアングルと高力ボルトを介して骨 組の梁に取り付けた。単体実験では、壁自体の弾塑性性状を調べる 為に、実験結果に接合部の挙動の影響が及ばないよう、幅 $800 \mathrm{~mm}$ 、 厚さ $4.5 \mathrm{~mm}$ の鋼板壁に対し、L-100x100x10 のアングルと M20(F10T) の高力ボルト 7本を用い、充分に剛な接合部にしていたが、今回は 実用的な寸法のアングルと高力ボルトを念頭に置き、同じ寸法の鋼 板壁に対し、アングルには L-50x50x6 を、高力ボルトには、W202 の耐震壁の計算耐力を上回る水平力に耐えられることを条件に、単 体実験と同じ個数の M12（F10T)の高力ボルトを使用した。 
$\mathbf{h}_{\mathbf{f}}$ : 層の高さ

$\mathrm{h}$ ：耐震壁の取付アングル内法高さ

$l_{\mathrm{b}}$ : 骨組のスパン

$l$ : 柱状部の高さ

b : 柱状部の幅

$\mathrm{h}_{\mathbf{w}}$ ：耐震壁の高さ

D：H形鋼（柱）のせい

d : H 形鐝 (梁) のせい

$\mathbf{h}_{\mathbf{c}}$ : 上梁下面と下梁上面間 の距離
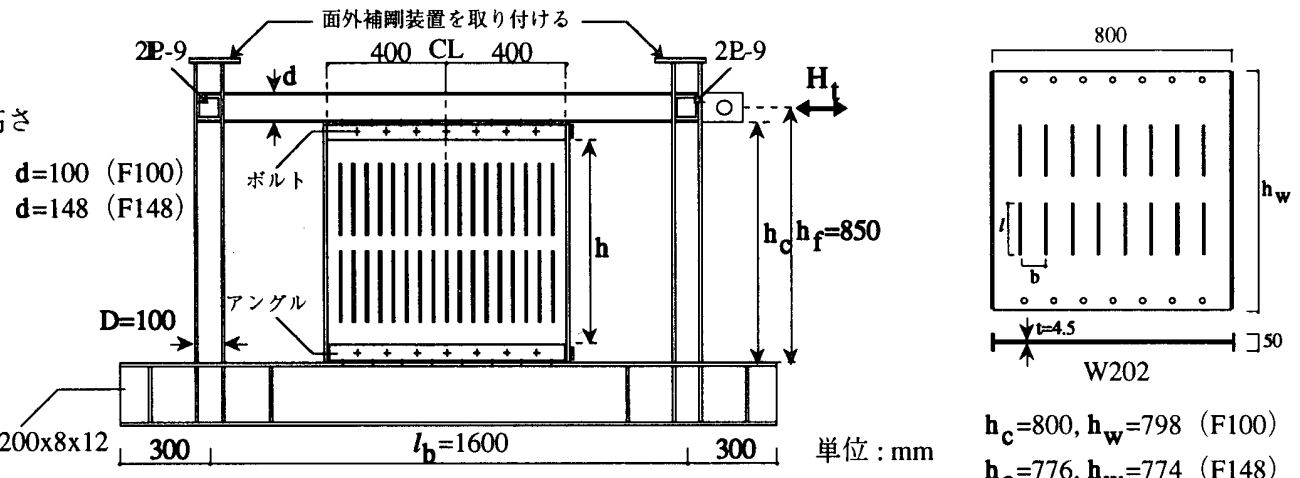

$\mathrm{H}-200 \times 200 \times 8 \times 12$

$\mathbf{h}_{\mathbf{c}}=800, \mathbf{h}_{\mathbf{w}}=798 \quad(\mathrm{~F} 100)$

$h_{c}=776, h_{w}=774 \quad(F 148)$

図2 試験体の一例(F100W102)

(1) (7): 変位計番号

1〜29 1 2 22 ひずみゲージ番号

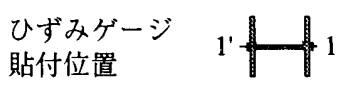

1-1'断面

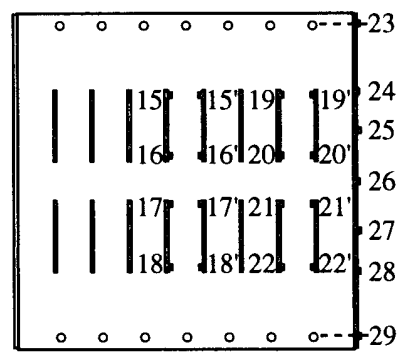

b) 糧荷方法

図 3 に示すように、試験体をロ形フレームに PC 鋼棒で固定し、 骨組の構面外の挙動を抑制する為に柱の延長部に面外変形抑制装置 を取り付けて、ロ形フレームに設置された油圧ジャッキを用いて梁 の断面中心に水平力を載荷した。

載荷プログラムは単体実験と同様に層間変形角 $\mathbf{R}$ を用いて決定 した。初めは $\mathbf{R}=0.25(\%) 、$ 次は $\mathbf{R}=0.5(\%) 、 そ の$ 後は $0.5(\%)$ ずつ漸 増させて $\mathbf{R}=5.0(\%)$ まで、各 $\mathbf{R} て ゙ ~ 1$ 回の正負交番繰返水平力載荷と した。

層間距離を単体実験ではアングルの内法高さ h としていたが、 本実験においては、梁の軸心と耐震壁の下端が取り付けられている $\mathrm{H}-200 \times 200 \times 8 \times 12$ の上フランジの上面の間の距離 $\mathbf{h}_{\mathbf{f}}$ とし、層間変形 角 $\mathbf{R}$ は、骨組の梁の水平変位 $\boldsymbol{\delta}$ を $\mathbf{h}_{\mathbf{q}}$ で除した值とした。また、単 体実験では層間変形角 $\mathbf{R}=3.0(\%)$ までで載荷を終えたが、今回は層 間変形角 $\mathbf{R}=5.0(\%)$ まで載荷を行った。
表2 実験変数

\begin{tabular}{c|c|c|c|c}
\hline \multirow{2}{*}{ 試験体名 } & \multicolumn{4}{|c}{ 実験変数 } \\
\cline { 2 - 5 } & 骨組 & \multicolumn{3}{|c}{ 耐震壁 } \\
\cline { 2 - 5 } & $\mathbf{K}_{\mathbf{b}} / \mathbf{K}_{\mathbf{c}}$ & $\mathbf{b}(\mathrm{cm})$ & $\boldsymbol{l}(\mathrm{cm})$ & $\mathbf{m}$ \\
\hline F100W000 & & - & - & - \\
F100W102 & \multirow{2}{*}{0.53} & 4.15 & 23.5 & 2 \\
F100W202 & & 8.60 & 16.8 & 2 \\
\hline F148W000 & & - & - & - \\
F148W102 & \multirow{2}{*}{1.41} & 4.15 & 23.5 & 2 \\
F148W202 & & 8.60 & 16.8 & 2 \\
\hline
\end{tabular}

$\mathrm{K}_{\mathrm{b}} / \mathrm{K}_{\mathrm{c}}$ : 柱に対する梁の剛比、 $\mathrm{b}, l, \mathbf{m}$ : 壁の柱状部の幅、高さ、層数 
架構に載荷される水平力（H）をロードセルで測定した。また、 大変形時でも弾性状態を保つ柱の 4 断面のフランジ表面 8 箇所にひ ずみゲージ（図 3 の A 及び B 枠内のひずみゲージ）を貼付し、柱 の各断面の曲率を測定し、この曲率と柱の断面 2 次モーメント及び ヤング率を用いて骨組の部分の水平力 $\left(\mathbf{Q}_{\mathbf{f}}\right)$ を求め、この $\mathbf{H}_{\mathbf{t}}$ と $\mathbf{Q}_{\mathbf{f}}$ との差を耐震壁の水平力 $\left(\mathbf{Q}_{\mathbf{w}}\right)$ とした。
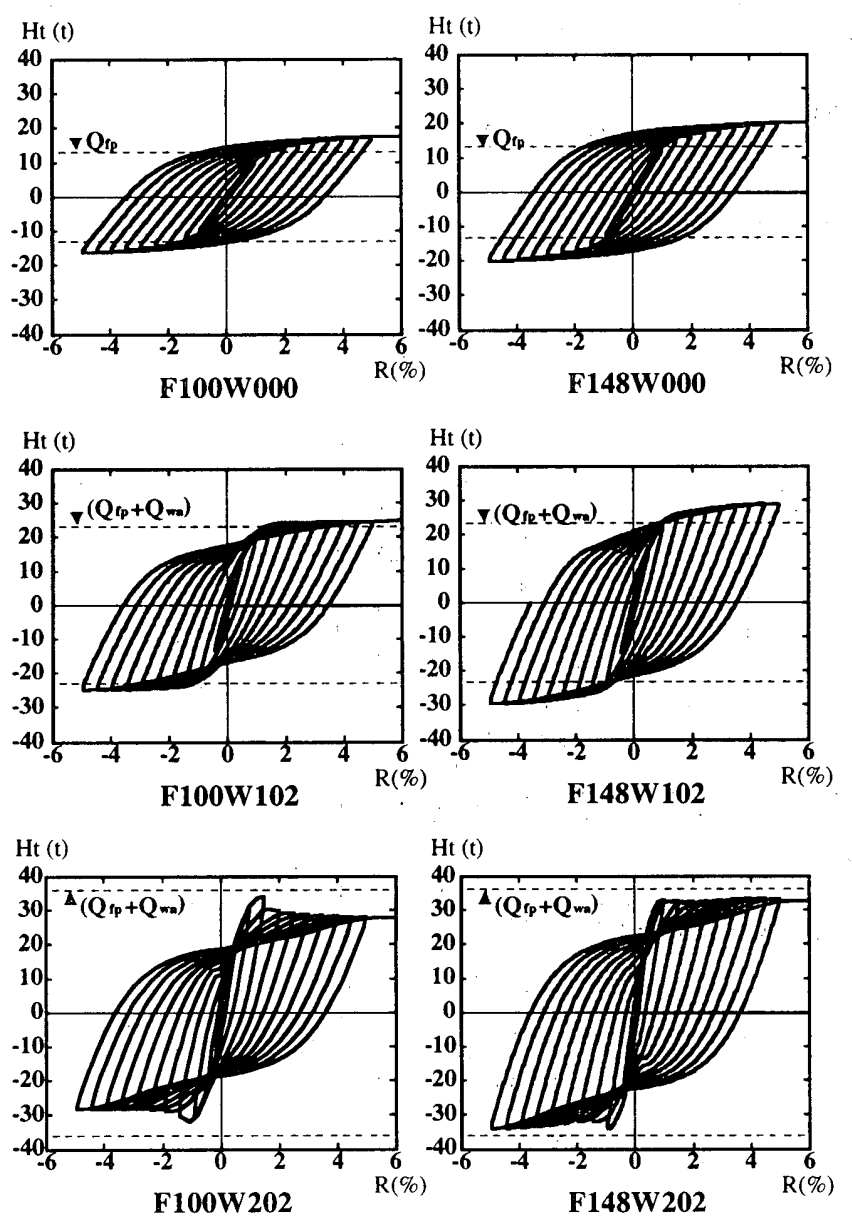

図 4 水平力 $\left(\mathbf{H}_{\mathbf{t}}\right)-$ 層間变形角 $(\mathbf{R})$ 関係
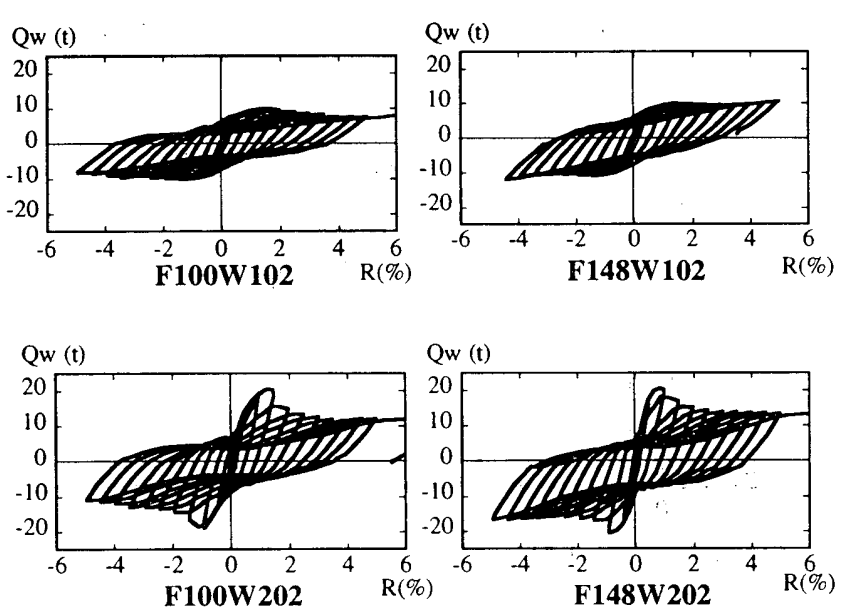

(骨組実験)

図 5 耐震壁の水平力 $\left(\mathbf{Q}_{w}\right)$ - 層間変形角 $(\mathbf{R})$ 関係
図 3 の中の(2)及び(3)の変位計で骨組の梁の水平変位 $\boldsymbol{\delta}$ を、(4) (7)の変位計で耐震壁の層間変位 $\boldsymbol{\delta}_{\mathrm{w}}$ を測定した。

前述の $\mathbf{Q}_{\mathbf{w}}$ 及び $\mathbf{Q}_{\mathbf{f}}$ を求める為のひずみゲージ以外にも、柱梁材 端付近の弾塑性状態や、梁の曲げモーメント分布を調べる為のひず みゲージを貼付した。耐震壁にも、柱状部端部の弾塑性状態とスチ フナの軸方向のひずみの分布を調べる為に、ひずみゲージを貼付し た。

\section{(2) 実験結果 \\ a) 弾盟性挙動}

\section{水平力一層間变形角関係}

架構に載荷された水平力 $\left(\mathbf{H}_{\mathbf{t}}\right)$ 及び耐震壁が負担する水平力 $\left(\mathbf{Q}_{\mathbf{w}}\right)$ - 層間変形角 $(\mathbf{R})$ 関係を図 4 及び図 5 に示す。図 6 には W102 及 びW202 の耐震壁の単体実験及び骨組実験の $\mathbf{Q}_{\mathbf{w}}-\mathbf{R}$ 関係の包絡線 の比較を示している。
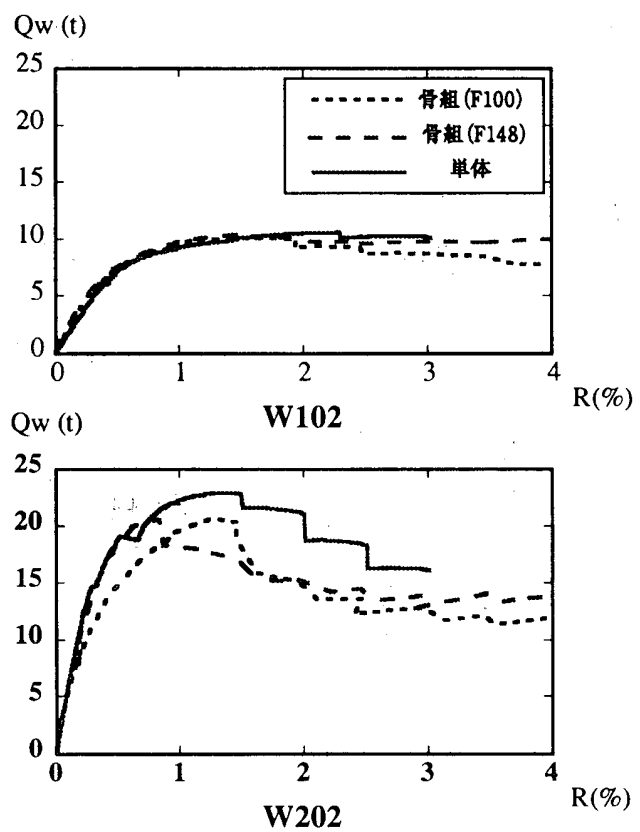

図6 $\mathbf{Q}_{\mathbf{w}}-\mathbf{R}$ 関係の包絡線
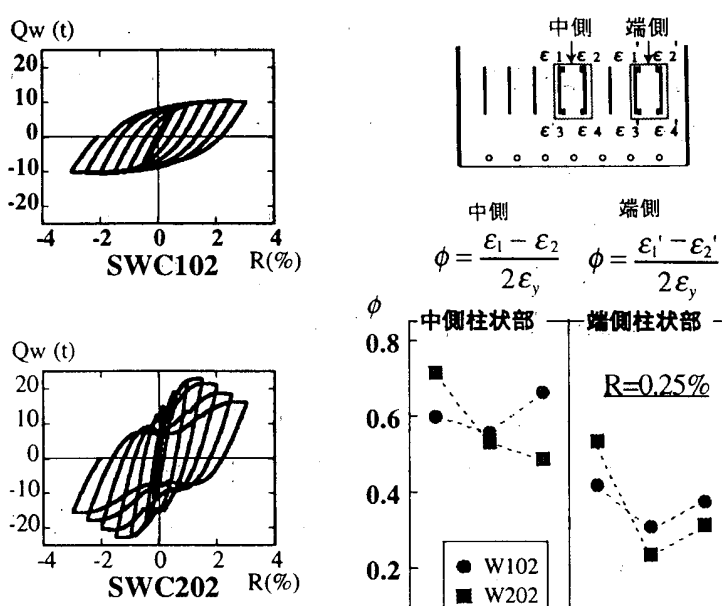

(単体実験)

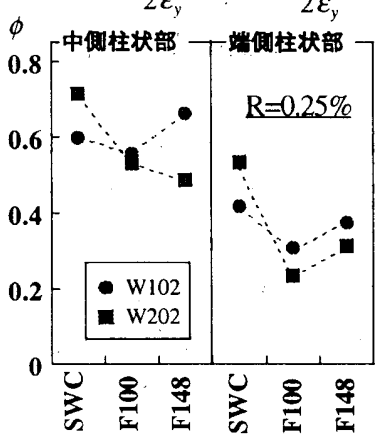

図 7 柱状部の無次元化曲率 
図 4 の破線は、柱材の降伏忍力度を用いて計算した柱の柱頭・柱 脚に塑性ヒンジができた場合の骨組の耐力（ $\left.\mathbf{Q}_{\mathrm{fp}}\right)$ または、 $\mathbf{Q}_{\mathrm{p}}$ と式 (1)による耐震壁の計算耐力 $\left(\mathbf{Q}_{\mathrm{wa}}\right)$ との和 $\left(\mathbf{Q}_{\mathrm{fp}}+\mathbf{Q}_{\mathrm{wa}}\right)$ である。耐 震壁無し架構は、F100 では層間変形角 $\mathrm{R}=1.5(\%)$ で、F148 では $\mathrm{R}=1.0(\%)$ で $\mathrm{Q}_{\mathrm{fp}}$ に到達している。

耐震壁付架構において、骨組の部分が負担する水平力 $\left(\mathbf{Q}_{\mathrm{f}}\right)$ と $\mathbf{R}$ との関係は耐震壁無し架構（F100W000 及びF148W000）の $\mathbf{H}_{\mathbf{t}}-\mathbf{R}$ 関係とほほ同じであり（従ってここで図は示さない)、全ての試験 体において $\mathbf{Q}_{\mathbf{f}}$ は層間変形が進むと共に増加し続ける。

耐震壁付架構では、耐震壁無し架構に比べて $\mathbf{R}$ がより小さい時 点で $\mathbf{H}_{\mathbf{1}}$ が最大值に近い值を迎えるようになるが、大きな層間変形 時に骨組の部分の水平力 $\mathbf{Q}_{\mathrm{f}}$ が最大值に達している一方で、図 5 か ら、耐震壁の水平力 $\mathrm{Q}_{\mathbf{w}}$ は $\mathrm{W} 102$ の耐震壁では $\mathbf{R}=1.5 \sim 2.0(\%)$ 時に、 W202 の耐震壁では $\mathbf{R}=0.5 \sim 1.0(\%)$ 時にピークに達しており、耐震壁 によって $\mathbf{R}$ が小さい時の架構全体の耐力が大きく高められている ことがわかる。

耐震壁の単体実験においては、W102 が紡錘形の安定した挙動を 示すのに対して、骨組実験では酎震壁の水平力 $\left(\mathbf{Q}_{\mathbf{w}}\right)$ が最大値に 達した後に耐震壁の面外変形によって、ややスリップ型の挙動が見 られる。W202 の耐震壁では単体実験でもスリップ型挙動は認めら れたが、骨組実験ではこのスリップ型挙動の傾向は強くなっている。

単体実験と骨組実験においては、図 6 の耐震壁の $\mathbf{Q}_{\mathbf{w}}-\mathbf{R}$ 関係の 包絡線から、耐震壁の水平力-層間変形角関係は、W102 では単体 実験と骨組実験とで余り変化が無かったのに対し、W202 では $\mathbf{Q}_{\mathbf{w}}$ が、特に梁剛比が小さい骨組に組込まれた時に、より小さい層間変 形時に単体の耐震壁をはっきりと下回るようになることがわかる。

\section{ひずみ挙動}

架構の柱材部分が降伏を開始するのは、F148 の骨組の方がやや 小さな層間変形角 $\mathbf{R}$ の時であったが、概ね、耐震壁の有無及び種 類に関わらず、 $\mathbf{R}=1.0 \sim 1.5(\%)$ の時であった。梁剛比が大きい F148 の骨組では梁が降伏することはなかったが、梁剛比が小さい F100 の骨組では、層間変形角 $\mathbf{R}=3.0(\%) の$ 時に、梁の耐震壁の傍の部分 (図 3 のひずみゲージ 12，12'，13，13’が貼付された部分）が降伏し た。
図 7 に、初期変形時である $\mathbf{R}=0.25(\%)$ 時における骨組実験の耐震 壁の中側と端側の柱状部の無次元化曲率 $\phi$ (図 7 参照) を、同じ層 間変形時の単体実験の $\phi$ と比較して W102に関しては○で、W202 に関しては國で示す。

どの耐震壁においても、中側の柱状部の申の方が端側の柱状部の фより大きく、特に骨組に組込まれた W202 の耐震壁の場合その差 が著しい。また、中側・端側を問わず単体実験の方が $\phi$ 大゙きく、 W202 の場合その差か顕著である。更に、梁の剛比が小さい骨組に 取付けられた耐震壁の方が、概ね、その差はやや大きくなる。

同じ層間変形か㴗震壁に生じている時に、単体実験と比較すると、 骨組実験の耐震壁の柱状部の $\phi$ がささなっており、特に端側の柱 状部の㒂しく小さくなっているということから、耐震壁が骨組 に組込まれた時には、全体曲げなどにより単体実験の場合より大き な壁板全体としての層間変形が生じ、端側の柱状部の上下端の拘束 は単体実験の場合よりかなり弱くなっているものと考えられる。

\section{b) 耐力}

実験耐力及び計算耐力とそ扎らの比較を表 3 に示す。 多くの試験体において、架構全体の耐力及び骨組の部分の耐力は、 層間変形角 $\mathbf{R}=5.0(\%)$ といった大きな層間変形時に最大となる。し かし、実際の設計においては層間変形角 $\mathbf{R}=2.0(\%)$ 以内での耐力が

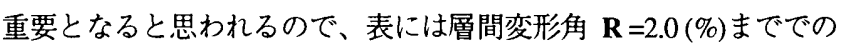
架構全体、耐震壁を除いた骨組の部分及び耐震壁の最大耐力（ $\mathbf{H}_{\mathfrak{w e}}$ $\mathbf{Q}_{\mathrm{fe}}$ 及び $\left.\mathbf{Q}_{\mathrm{we}}\right)$ を( i )、(ii) 及び(iii)に示している。

表中の $\mathbf{Q}_{\mathbf{f i e}}$ 及び $\mathbf{Q}_{\text {wie }}$ は、順に、骨組実験における耐震壁無し架

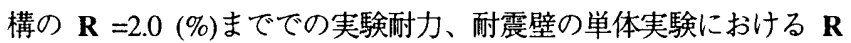
$=2.0(\%)$ まででの実験耐力で、これらの值と $\mathbf{H}_{\mathrm{te}}, \mathbf{Q}_{\mathrm{fe}}$ 及び $\mathbf{Q}_{\mathrm{we}}$ との

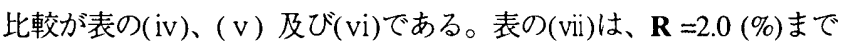
での実験耐力に対する実験終了時まででの架構全体の最大耐力 $\left(\mathbf{H}_{\mathbf{t e}}\right.$ ${ }_{\max }$ ）の比を示す。 $\mathbf{Q}_{\mathbf{w a}}$ は提案式(1)で求められる計算耐力であり、 $\mathbf{Q}_{\mathrm{fp}}$ はa)でも示した、柱材の降伏応力度を用いて計算した柱の柱頭・ 柱脚に塑性ヒンジができた場合の骨組の耐力で、これらの計算耐力 と層間変形角 $\mathbf{R}=2.0(\%)$ まででの耐力 $\left(\mathbf{H}_{\mathrm{te}}\right.$ 及び $\left.\mathbf{Q}_{\mathbf{w e}}\right)$ とを比較し たのが表の(viii)及び(ix)である。

表 3 実験耐力及び計算耐力との比較

\begin{tabular}{|c|c|c|c|c|c|c|c|c|c|}
\hline \multirow{3}{*}{ 試験体名 } & \multicolumn{3}{|c|}{ 実験耐力 } & \multicolumn{3}{|c|}{ 骨組実験耐力 /単体実験耐力 } & \multirow{2}{*}{\begin{tabular}{|c|} 
最大 $/ \mathbf{R}=2.0 \%$ \\
(vii) \\
\end{tabular}} & \multicolumn{2}{|c|}{ 実験耐力 /計算耐力 } \\
\hline & (i) & (ii) & (iii) & (iv) & (v) & (vi) & & (viii) & (ix) \\
\hline & $\mathbf{H}_{\mathrm{te}}(\mathbf{t})$ & $Q_{\mathrm{fe}}(t)$ & $Q_{w e}(t)$ & $\mathbf{H}_{\mathrm{te}} / \mathbf{Q}_{\mathrm{fie}}$ & $\mathrm{Q}_{\mathrm{fe}} / \mathbf{Q}_{\mathrm{fie}}$ & $\mathbf{Q}_{\text {we }} / \mathbf{Q}_{\text {wie }}$ & $\mathbf{H}_{\mathrm{te} \mathrm{max}} / \mathbf{H}_{\mathrm{te}}$ & $Q_{w e} / Q_{w a}$ & $\mathbf{H}_{\mathrm{te}} /\left(\mathbf{Q}_{\mathrm{fp}}+\mathbf{Q}_{\mathrm{wa}}\right)$ \\
\hline F100W000 & 13.7 & 13.7 & - & 1.00 & 1.00 & - & 1.30 & - & 1.05 \\
\hline F100W 102 & 24.1 & 14.2 & 10.1 & 1.75 & 1.03 & 1.03 & 1.08 & 1.15 & 1.04 \\
\hline F100W202 & 34.1 & 14.3 & 21.1 & 2.48 & 1.04 & 0.94 & 1.00 & 0.80 & 0.95 \\
\hline F148W000 & 16.3 & 16.2 & - & 1.00 & 1.00 & - & 1.25 & - & 1.23 \\
\hline F148W102 & 26.4 & 16.5 & 10.2 & 1.63 & 1.01 & 1.04 & 1.09 & 1.16 & 1.13 \\
\hline F148W202 & 32.7 & 17.8 & 20.6 & 2.02 & 1.10 & 0.92 & 1.01 & 0.78 & 0.91 \\
\hline
\end{tabular}

$\mathbf{H}_{\mathrm{te}}$ : 層間変形角 $(\mathbf{R})$ が $2(\%)$ 以下での架構全体の最大耐力、 $\mathbf{Q}_{\mathrm{fe}}: \mathbf{R}$ が2(\%)以下での骨組の部分の最大耐力、 $\mathbf{Q}_{\mathrm{we}}: \mathbf{R}$ が $2(\%)$ 以下での 耐震壁部分の最大耐力、 $\mathbf{Q}_{\mathrm{fie}}$ ：R が 2(\%)以下での耐震壁無し架構の最大耐力（F100W000 及び $F 148 W 000$ の $\mathbf{Q}_{\mathrm{fe}}$ )、 $\mathbf{Q}_{\text {wie }}: \mathbf{R}$ が $2(\%)$ 以下 での単体の耐震壁の最大耐力、 $\mathbf{Q}_{\mathbf{w a}}$ ：耐震壁の計算耐力（式(1)による)、 $\mathbf{H}_{\mathbf{t e}}$ max : 実験最終時 $(\mathbf{R}=5.0(\%)$ ) まででの架構の最大耐力、 $\mathbf{Q}_{\mathfrak{f p}}$ : 柱材の降伏応力度を用いて計算した柱の柱頭・柱脚に塑性ヒンジができた場合の骨組の部分の耐力. 
表 3(iv)の $\mathbf{H}_{\mathrm{ue}} / \mathbf{Q}_{\mathrm{fe}}$ : は、耐震壁が取り付けられることによる、架構 の耐力の増加を示す。この值から、耐震壁によって骨組のみの場合 の 1.63 2.48 倍に耐力が増加することがわかる。また、耐震壁が取 り付けられた場合と耐震壁が無い場合との骨組の部分の最大耐力の 比 $\left(\mathbf{Q}_{\mathrm{fe}} / \mathbf{Q}_{\mathrm{fie}}:\right.$ 表の $\left.(\mathrm{v})\right)$ から、 $\mathbf{R}=2.0(\%)$ までの間で、耐震壁の有 無によって骨組の部分が発揮する两力は殁ど変化しないことがわか る。

一方、耐震壁に関しては、骨組に組込まれた耐震壁と単体の耐震 壁との最大耐力の比較 $\left(\mathbf{Q}_{\mathrm{we}} \mathbf{Q}_{\mathbf{w l e}}\right.$ : 表の(vi)) を見ると、W102.の 耐震壁では殆ど変化が無いのに対し、W202 の耐震壁に挹いては単 体の耐震壁より骨組に組込まれた耐震壁の方がやや小さい。

W202 の試験体は単体実験において、最大雱力発揮と同時に面外 挙動を始め、その後大きく面外に变形した 2。単体実験の耐震壁は 梁に取り付ける為のアングルの内法スパン（h）が $600 \mathrm{~mm}$ であっ たのに対し骨組実験では約 $700 \mathrm{~mm}$ で、耐震壁の面外变形が拘束さ れない部分の高さが大きくなった為、面外挙動の開始が単体実験耐 力に到達する前に始まったことが原因と考えられる。

耐震壁の耐力に関しては、既往の単体実験 ${ }^{3}$ より、前述の面外挙 動の為、b/t が大きくなると実験値と計算値との対応が悪くなるこ とがわかっている。単体実験の耐力と骨組実験の耐力は概ねよい対 応をしているが、W202 のような b/t が大きい場合には、単体の場 合の耐力評価式に低隇倸数を乗じて骨組に組込ま机た場合の耐力評 価を行う必要がある。

c) 㓮性

実験剛性及び計算剛性とそれらの比較を表 4 に示す。
層間変形角 $\mathbf{R}=0.25(\%)$ まででの水平力ー層間変形角関係の勾配を 実験剛性とし、表 4 には、架構全体、耐震壁を除いた骨組の部分及 び耐震壁のそれぞれの実験剛性 $\mathbf{K}_{\mathbf{t e}} 、 \mathbf{K}_{\mathbf{f e}} 、 \mathbf{K}_{\mathbf{w e}}$ を( i )、(ii) 及び(iii) に示している。後の（iv)、(vi)、(vii) の剛性の比較に用いられ る $\mathbf{K}_{\text {fie }}$ 及び $\mathbf{K}_{\text {wie }}$ は、耐震壁が骨組に組込まれていない場合の骨組 及び耐震壁の実験剛性（耐震壁無し架構及び単体の耐震壁の実験剛 性）である。(iv)、(vi）及び（viii) は、耐震壁が組込まれない場 合に対する耐震壁付架構の、架構全体の剛性、骨組の部分の剛性及 び耐震壁の部分の剛性の比を表す。

（iv）及び（vi）から耐震壁を取りつけることにより、特に剛 性が大きいW202 の場合には、架構全体では 5 6 倍に剛性が増大 し、骨組部分の剛性も耐震壁による梁の変形に対する拘束によって 単体の時よりもやや大きくなる。

一方で、骨組に組込まれると耐震壁の剛性は単体実験の場合と比 較して（(viii)）大きく減少する。(ix)の $\mathbf{K}_{\mathrm{wa}}$ は提案式(2)による耐 震壁の計算剛性を示すが、この計算剛性との対応も悪くなる。

単体実験と骨組実験で異なる点は、梁と耐震壁の相互の応力伝達 にある。この相立作用を調べる為に、架構の梁のひずみゲージで、 層間变形角 $\mathbf{R}=0.25$ 及び $0.5(\%)$ 時の梁の曲げモーメント分布を調べ た。

梁の曲げモーメント分布を耐震壁付架構と酎震壁無し架構とで 比較すると、図 8 の(a)と(c)に示すような違いがある。耐震壁付骨 組では、耐震壁には梁からの応力が上端のアングルとボルトを介し て伝わる。

表 4 実験剛性び計算剛性との比較

\begin{tabular}{c|c|c|c|c|c|c|c|c|c}
\hline \multirow{2}{*}{ 試験体名 } & ( i ) & (ii) & (iii) & (iv) & ( v ) & (vi) & (vii) & (vii) & (ix) \\
\cline { 2 - 10 } & $\mathbf{K}_{\mathbf{t e}}$ & $\mathbf{K}_{\mathbf{f e}}$ & $\mathbf{K}_{\mathbf{w e}}$ & $\mathbf{K}_{\mathbf{t e}} / \mathbf{K}_{\text {fie }}$ & $\mathbf{K}_{\mathbf{w e}} / \mathbf{K}_{\mathbf{f e}}$ & $\mathbf{K}_{\mathbf{r e}} / \mathbf{K}_{\text {rie }}$ & $\mathbf{K}_{\mathbf{f e}} / \mathbf{K}_{\text {fia }}$ & $\mathbf{K}_{\mathbf{w e}} / \mathbf{K}_{\mathbf{w i e}}$ & $\mathbf{K}_{\mathbf{w e}} / \mathbf{K}_{\mathbf{w a}}$ \\
\hline F100W000 & 14.3 & 14.3 & - & 1.00 & - & 1.00 & 1.00 & - & - \\
F100W102 & 40.0 & 15.1 & 24.8 & 2.79 & 1.64 & 1.06 & 1.22 & 0.86 & 0.94 \\
F100W202 & 71.2 & 17.3 & 54.0 & 4.98 & 3.12 & 1.21 & 1.28 & 0.47 & 0.48 \\
\hline F148W000 & 16.3 & 16.3 & - & 1.00 & - & 1.00 & 1.00 & - & - \\
F148W102 & 43.2 & 18.2 & 25.0 & 2.65 & 1.37 & 1.12 & 1.10 & 0.87 & 0.94 \\
F148W202 & 83.3 & 19.6 & 63.7 & 5.11 & 3.26 & 1.20 & 1.16 & 0.56 & 0.57 \\
\hline
\end{tabular}

$\mathbf{K}_{\mathbf{x}}:$ 架構の実験剛性、 $\mathbf{K}_{\mathbf{k}}$ :骨組部分の実験剛性、 $\mathbf{K}_{\mathbf{m e}}$ : 耐震壁部分の実験剛性、 $\mathbf{K}_{\mathbf{f}}$ : 酎震壁無し架構の実験剛性、 $\mathbf{K}_{\mathbf{f}}:$ 式(6)による骨組の部 分の計算剛性、 $\mathbf{K}_{\mathrm{ma}}$ :式(6)に $\mathbf{P}=0$ を代入した、耐震壁無し架構の計算剛性、 $\mathbf{K}_{\mathrm{wiz}}$ : 耐震壁の単体実験剛性、 $\mathbf{K}_{\mathrm{wa}}$ :式(2)による単体の耐震 壁の計算剛性.

剛性の単位: $(\mathrm{t} / \mathrm{cm})$

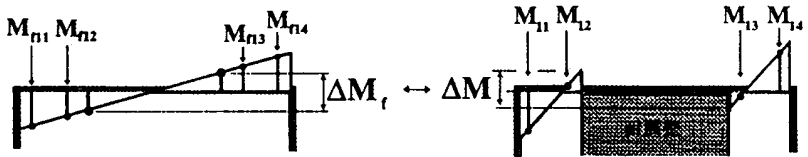

(c) 耐震壁付架構の

(a) 耐祳壁無し架桠の

梁の曲げモーメン分布

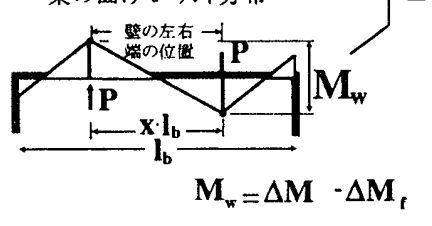

(b) 耐震壁から伝わる 忘力Pによる梁の曲げモーメント分布
重ね合せ 三 梁の曲げモーメント分布

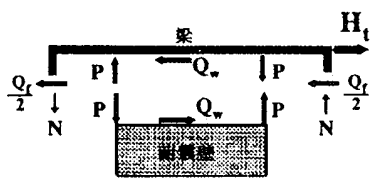

(d) 耐震壁と骨組との 応力伝達

図8 梁の曲げモーメント分布

表 5 梁にかかる鉛直力と柱の軸力

\begin{tabular}{c|c|c|c|c|c|c|c|c}
\hline \multirow{2}{*}{ 試験体名 } & \multicolumn{4}{|c|}{$\mathrm{R}=0.25 \%$ 時 } & \multicolumn{4}{c}{$\mathrm{R}=0.5 \%$ 時 } \\
\cline { 2 - 9 } & $\mathbf{P}$ & $\mathbf{N}$ & $\mathbf{N}_{\mathbf{e}}$ & $\mathbf{P} / \mathbf{P}_{\mathbf{i}}$ & $\mathbf{P}$ & $\mathbf{N}$ & $\mathbf{N}_{\mathbf{e}}$ & $\mathbf{P} / \mathbf{P}_{\mathbf{i}}$ \\
\hline F100W102 & 2.33 & 1.27 & 0.97 & 0.99 & 3.58 & 1.95 & 1.95 & 0.90 \\
\hline F100W202 & 3.24 & 1.77 & 1.96 & 0.46 & 6.01 & 3.27 & 3.66 & 0.64 \\
\hline F148W102 & 2.42 & 1.26 & 1.02 & 1.07 & 4.80 & 2.50 & 1.81 & 1.21 \\
\hline F148W202 & 3.99 & 2.08 & 2.51 & 0.55 & 6.80 & 3.54 & 4.32 & 0.72 \\
\hline
\end{tabular}

$\mathbf{P}$ : 図 8 (b) に示す $\mathbf{M}_{\mathbf{w}}$ を用いて式(3)で求めた梁にかかる鉛直力、 $\mathbf{N} ： \mathbf{P}$ を用いて式(4)で求めた骨組の柱にかかる軸力、 $\mathbf{N}_{\mathrm{e}}$ : ひずみ ゲージで計測した柱の軸力から耐震壁無し架構の軸力を引いた 值、 $\mathbf{P}_{\mathbf{i}}$ : 単体の耐震壁に作用すると仮定して求めた鉛直力. 力の単位 : ( $\mathrm{t}$ ) 
伝達される鉛直方向応力が、図 8 の(b)に示す $\mathbf{P}$ のような耐震壁 の左右両端部の集中荷重であると考えると、上記の耐震壁の有無に よって生じる曲げモーメントの分布の差はこの P によるものであ り、翻ると、耐震壁付骨組の梁の曲げモーメント分布（M）から耐 震壁無し骨組の梁の曲げモーメント分布 $\left(\mathbf{M}_{\mathbf{f}}\right)$ を差し引くと $\mathbf{P}$ に よる梁の曲げモーメント分布となる。

図 8 (b)のように骨組に耐震壁の左右両端部から P がかかる時の $\mathbf{P} 、 \mathbf{P}$ の加力点での曲げモーメント $\mathbf{M}_{\mathbf{w}}$ 及び柱の軸力 $\mathbf{N}$ の関係は次 の式(3)及び(4)で表される。

$$
\begin{aligned}
& \mathbf{P}=\frac{\mathbf{K}_{\mathrm{c}}+6 \mathbf{K}_{\mathrm{b}}}{\left(\mathbf{x}^{2}+1\right) \mathbf{K}_{\mathrm{c}}+12 \mathbf{K}_{\mathrm{b}}} \cdot \frac{4}{\mathbf{x}} \cdot \frac{\mathbf{M}_{\mathrm{w}}}{\mathbf{l}_{\mathrm{b}}} \\
& \mathbf{N}=\frac{\left(3 \mathbf{x}^{2}-1\right) \mathbf{K}_{\mathrm{c}}+12 \mathbf{K}_{\mathrm{b}}}{\mathbf{K}_{\mathrm{c}}+6 \mathbf{K}_{\mathrm{b}}} \cdot \frac{\mathbf{x}}{2} \cdot \mathbf{P}
\end{aligned}
$$

ここで、 $\mathbf{K}_{\mathbf{c}}$ : 柱の剛度、 $\mathbf{K}_{\mathbf{b}}$ : 梁の剛度、 $\mathbf{l}_{\mathbf{b}}$ : 梁の長さ $(=160 \mathrm{~cm}) 、$ $\mathbf{x}$ : 耐震壁の幅の梁の長さ $\left(\mathrm{I}_{\mathrm{b}}\right)$ に対する比 $(\mathrm{x}=0.5)$ 。

耐震壁にかかる鉛直力に関する前述の仮定が正しいとして、各試 験体に対して、ひずみゲージで測定した梁の 4 断面の曲げモーメン ト $\left(\mathbf{M}_{11 \sim 14}\right)$ から $\mathbf{P}$ の加力点間での曲げモーメントの差（ $\Delta \mathbf{M}$ : 耐 震壁付骨組、 $\Delta \mathbf{M}_{\mathbf{f}}$ : 壁無し骨組）を求め、 $\Delta \mathbf{M}$ と $\Delta \mathbf{M}_{\mathbf{f}}$ の差を $\mathbf{M}_{\mathbf{w}}$ と した（図 8 (b) 参照)。

層間変形角 $\mathbf{R}=0.25(\%)$ 及び $\mathbf{R}=0.5(\%)$ 時の、 $\mathbf{M}_{\mathbf{w}}$ を用いて式(3)及び (4)により $\mathbf{P}$ と $\mathbf{N}$ を計算した結果を表 5 に示す。

また、 $\mathbf{R}=0.25(\%)$ 及び $\mathbf{R}=0.5(\%)$ 時の、ひずみゲージで計測した耐 震壁付架構の柱の軸力から、同じくひずみゲージで計測した耐震壁 無し架構の軸力を引いた值 $\mathbf{N}_{\mathrm{e}}$ を表に示す。 $\mathbf{R}=0.25(\%)$ 及び $\mathbf{R}=0.5(\%)$ 時の耐震壁を除く骨組の部分が負担する水平力は、耐震壁付架構と 耐震壁無し架構では余り変わらないので、 $\mathbf{N}_{\mathbf{e}}$ は $\mathbf{P} に よ り$ 柱に生じ ている軸力であると言える。

表中の $\mathbf{N}$ と $\mathbf{N}_{\mathrm{e}}$ の值を比較すると、梁の曲げモーメントから求め た軸力 $\mathbf{N}$ と、実測した $\mathbf{N}_{\mathrm{e}}$ の值が比較的近い值であることがわかり、 図 8 (b)のように耐震壁の左右両端に作用する集中荷重 P の仮定は 妥当であると思われる。

単体実験においても同様に、耐震壁の上端と下端で同じ大きさの 集中荷重 $\mathbf{P}_{\mathbf{i}}$ が左右端部にかかると仮定して、 $\mathbf{P}_{\mathbf{i}}$ を次の式(5)で求め る。

$$
\mathbf{P}_{\mathbf{i}}=\frac{\mathbf{Q}_{w} \cdot\left(\mathbf{h}_{w} / 2\right)}{\mathbf{x l}_{\mathbf{b}}}
$$

ここで、 $\mathbf{Q}_{\mathbf{w}}$ : 耐震壁の剪断力、 $\mathrm{h}_{\mathrm{w}}$ : 耐震壁の高さ $(=80 \mathrm{~cm})$ 。

$\mathbf{R}=0.25$ 及び 0.5(\%)時の、P の $\mathbf{P}_{\mathbf{i}}$ に対する比（P/P $)$ を同じく表 5 に示す。 $\mathbf{R}=0.25(\%)$ の時は、 $\mathbf{P} / \mathbf{P}_{\mathbf{i}}$ の值は $\mathrm{W} 102$ が取り付けられた架 構では 1 に近いが、W202 が取り付けられた架構では著しく 1 より 小さくなっている。このことから単体実験と比較して骨組実験では 梁によるW202の上端の固定度はかなり小さくなっていることがわ かる。この耐震壁の上端の固定度の低下により、壁板の全体曲げ変 形がより大きくなり、同時に、a)弾塑性挙動のひずみ举動で記した ように、端側の柱状部の上下端の拘束が弱くなり抵抗力が減少した 為、耐震壁の剛性が低下したものと考えられる。
また、W202 が取り付けられた架構に関して $\mathbf{R}=0.25(\%)$ の時と比 較すると、 $\mathbf{R}=0.5(\%)$ の $\mathbf{P} / \mathbf{P}$, の值は 3 4 割増加し、1 に近くなってお り、層間変形が進むと、耐震壁の上下端の梁による拘束力の単体実 験と骨組実験との差は小さくなることがわかる。

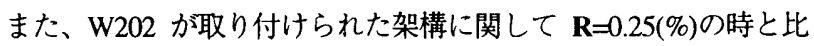
較すると、 $\mathbf{R}=0.5(\%)$ の $\mathbf{P} / \mathbf{P}_{\mathbf{i}}$ の值は 3 4 割増加し、1に近くなってい

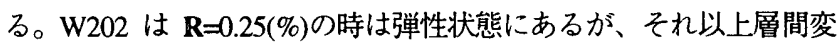
形が進み柱状部が塑性化すると、骨組に組込まれたW202 の応力状 態は単体の場合の W202 の応力状態に近くなり、上端の梁による拘 束力の単体実験と骨組実験との差は小さくなるものと考えられる。

一方で、図 8 のように水平力 $\mathbf{Q}_{\mathbf{f}}$ と鉛直力 $\mathbf{P}$ が載荷される骨組の $\mathbf{Q}_{\mathbf{f}}$ に対する剛性 $\mathrm{K}_{\mathrm{fa}}$ は次式(6)で表される。

ここで、 $\mathbf{c}$ : 階高 $(=85 \mathrm{~cm})$ 。

$\mathbf{K}_{\mathbf{f a}}=1 /\left\{\frac{2 \mathbf{K}_{\mathrm{c}}+3 \mathbf{K}_{\mathbf{b}}}{6 \mathbf{K}_{\mathbf{c}}\left(\mathbf{K}_{\mathbf{c}}+6 \mathbf{K}_{\mathbf{b}}\right)} \cdot \mathbf{l}_{\mathbf{c}}{ }^{2}-\frac{1}{\mathbf{K}_{\mathbf{c}}+6 \mathbf{K}_{\mathbf{b}}} \cdot \frac{\mathbf{x}\left(1-\mathbf{x}^{2}\right)}{4} \cdot \mathbf{l}_{\mathbf{b}} \mathbf{l}_{\mathbf{c}} \frac{\mathbf{P}}{\mathbf{Q}_{\mathbf{t}}}\right\}(6)$

表 4 の（vii）に層間変形角 $\mathbf{R}=0.25(\%)$ 時の $\mathbf{Q}_{\mathbf{f}}$ と $\mathbf{P}$ の実験値を もちいて計算した $\mathbf{K}_{\mathbf{f a}}$ の、 $\mathbf{P}=0$ として計算した耐震壁が組込まれて いない場合 $\left(\mathbf{K}_{\mathrm{ffa}}\right)$ との比較 $\left(\mathbf{K}_{\mathrm{fa}} / \mathbf{K}_{\mathrm{fia}}\right)$ を示す。実験結果 $\left(\mathbf{K}_{\mathrm{fe}} / \mathbf{K}_{\mathrm{fle}}\right.$ : (vi)）との対応が良いとは言えないが、耐震壁が取りつけられる ことによって、1〜2 割程度の骨組の部分の岡性が増加することが わかる。

以上のように、耐震壁が骨組に組込まれると、耐力に関しては骨 組と耐震壁の双方に関して余り問題は無いが、剛性に関しては W202 のような剛性の大きな耐震壁に大きな剛性低下が生じる。ま た、W202 の耐震壁は最大耐力発揮後の耐力少化は無視できず、現 段階での実用化は $\mathbf{b} / \mathbf{t}<20$ の耐震壁に限定すべきと思われる。
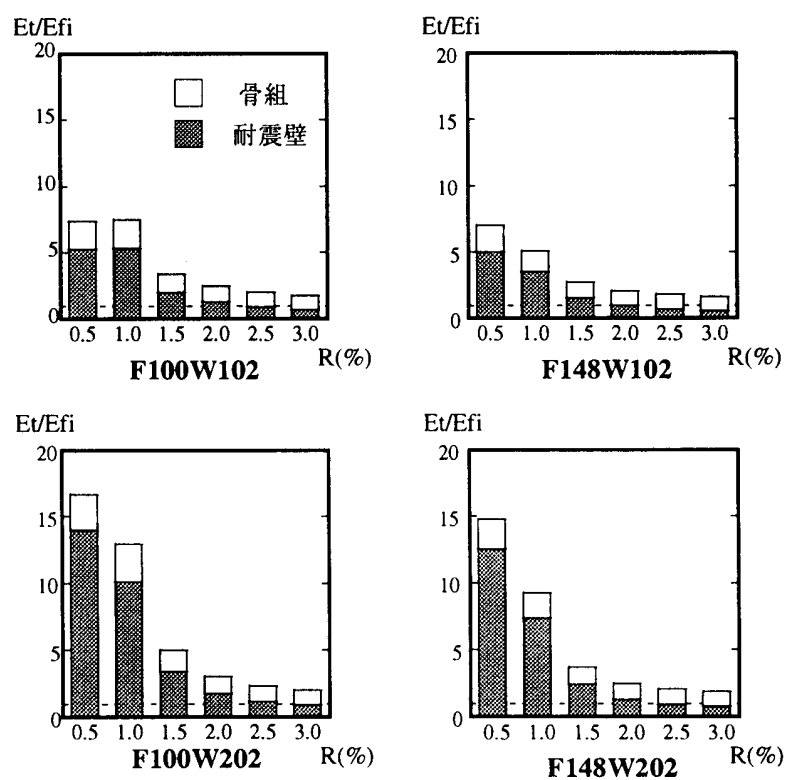

Et ：耐震壁付架構の吸収エネルギー

Efi：耐震壁無し架構の吸収エネルギー 


\section{d) エネルギー吸収能力}

図 9 に各層間変形角 $\mathbf{R}$ まででの耐震壁付き試験体のエネルギー 吸収量を骨組と耐震壁の負担量に分けて示している。吸収エネルギ 一量は、各 $\mathbf{R}$ 時までの架構全体の吸収エネルギー量 $(\mathrm{Et})$ ，を耐震 壁無し試験体のエネルギー量（Efi）で無次元化している。

耐震壁が取り付けられることによって、層間変形角 $\mathbf{R}=1.0(\%)$ ま での架構のエネルギー吸収量が大きく増大しているが、特に剛性が 高いW202 の耐震壁付架構において、吸収エネルギーの増大は大き

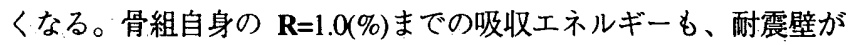
取り付けられることによって大きくなる。

\section{4. 結論}

単体実験により単体での性質が明らかになっているスリット入り 鋼板耐震壁を骨組に組込んた時の挙動を調べる為に、門形骨組の柱 に対する梁の剛比（F100 及び F148）と、スリット入り鋼板䡎震壁 の有無及び種類（耐震壁無し、W102 及びW202）を実験变数とし、 普通龬である SS400 を用いて、計 6 体の試験体を製作し、繰返水 平力載荷実験を行った。

実験の結果、次のことがわかった。

1. 耐震壁は骨組に組込まれた場合でも、単体実験で観察されたよ うな勒性がある曲げ挙動をする。

2. 架構の骨組部分の履歴ループの形状や最大耐力は、概ね耐震壁 の有無及び種類による变化が無く、耐力も耐震壁の有無により 殆ど左右さ机ない。

3. 架構内での耐震壁の耐力は、概ね単体の耐震壁の耐力と等しく、 単体の場合と同じように期待することができる。

4. 骨組に耐震壁が組込まれると、耐震壁により梁の変形が拘束さ れる為、骨組の部分の郕性は 1 2 割程度増加する。

5. 架構内での耐震壁の剛性は、単体実験と比較すると特に単体で の剛性が高い耐震壁で減少する。

6. 架構内での耐震壁は、骨組部分に比べて層間変形が小さい時に 塑性化を開始し、架構の初期変形時（R=1.0(\%)まで）の吸収工 ネルギー量を大きく増大させる。

本実験結果から、W102 のような剛性が余り大きくない耐震壁は 実用化可能であることが検証された。

[謝辞]

本研究につきましては、日本鋼管(株)の岡本晴仁氏から貴重なご 意見を賜りました。ここに深く感謝の意を表します。また、実験に 関しては久島昭久技官、有働文久技官に御協力頂きました。どうも 有り難うございました。

[参考文献]

1）井上一朗:履歴型ダンパーを用いた耐震設計、シンポジウム「耐 震設計の一つの新しい万向」資料、pp95-111、1995.9

2）日高桃子、松井千秋、今村輝武、畑戸龍夫：スリット入り鋼板 耐震壁の弾塑性性状について、日本建築学会構造系論文集、第 519 号、pp111-117、1999.5
3）貞包佳秀、松井千秋、日高桃子、柳田幸久：スリット入り鋼板 耐震壁の構造性能 - 耐力・剛性のための調整变数について - 、 日本建築学会大会学術梗概集、pp797-8、1999.9

(1999年 7 月 10 日原稿受理, 2000 年 4 月 13 日採用決定) 